\title{
Proteomics of acute heart failure in a rat post-myocardial infarction model
}

\author{
YICHEN GUO $^{1}$, LIANQUN CUI ${ }^{1}$, SHILIANG JIANG ${ }^{1}$, AIRONG ZHANG ${ }^{2}$ and SHU JIANG ${ }^{3}$ \\ ${ }^{1}$ Department of Cardiology, Shandong Provincial Hospital Affiliated to Shandong University; ${ }^{2}$ Department of Cardiology, \\ Shandong Zhongqi Hospital; ${ }^{3}$ Department of Surgery, Huaiyin People's Hospital, Jinan, Shandong 250021, P.R. China
}

Received May 31, 2016; Accepted April 7, 2017

DOI: $10.3892 / \mathrm{mmr} .2017 .6820$

\begin{abstract}
The aim of the present study was to identify the mechanisms underlying the development of post-myocardial infarction (post-MI) heart failure. The left anterior descending coronary artery of rats was occluded to mimic human ischemic heart disease. Linear Trap Quadropole OrbiTrap mass spectrometry was used to profile the expressions of energy metabolism-associated and calcium-binding proteins in the post-MI and control groups. Using the online Protein Analysis Through Evolutionary Relationships classification system, 78 differentially expressed proteins were identified, including 50 downregulated proteins and 28 upregulated proteins in post-MI group when compared with the control group. The differentially expressed proteins were closely associated with energy metabolism, contractile function, calcium handling, pathological hypertrophy and cardiac remodeling. These results were further validated using western blotting. At different postoperative time points (1st and 14th day following surgery) during the progression of advanced heart failure post-MI, dynamic alterations in differential protein expression were identified. The expression of the vitamin D protein was significantly upregulated on the 1st day post-MI however, was then downregulated with progression of the disease on the 14th day post-MI. These results identified various target proteins associated with the disease, which may be used as diagnostic markers.
\end{abstract}

\section{Introduction}

Heart failure is a progressive and complex clinical syndrome that leads to impaired functional cardiac ability. It is defined as a symptom resulting in ventricular dysfunction (1) and is

Correspondence to: Professor Lianqun Cui, Department of Cardiology, Shandong Provincial Hospital Affiliated to Shandong University, 324 Jingwuweiqi Road, Jinan, Shandong 250021, P.R. China

E-mail: xc@sdcqm.com.cn

Key words: Linear Trap Quadropole OrbiTrap, acute heart failure, calcium-binding proteins characterized by high morbidity and mortality. Contractile dysfunction is often linked to chronic energy deficiency and ventricular remodeling. It has previously been reported that $\sim 50-60 \%$ of patients with heart failure have an enlarged left ventricle (LV) chamber and reduced ejection fraction $(2,3)$. The majority of patients with heart failure have a history of hypertension and LV hypertrophy (4). A pronounced decrease in free fatty acid (FFA) $\beta$-oxidation in dilated cardiomyopathy has been identified in patients with Class II and III heart failure according to the New York Heart Association classifications when compared with age-matched healthy individuals $(5,6)$. The same study additionally reported that during the progression of congestive heart failure, the increased ventricular remodeling elevated local oxygen consumption, and worsened the induced energy deficiency and ejection function. As a result, the heart enters a cycle of impaired cardiac functioning. However, the understanding of differential protein expression in post-myocardial infarction (post-MI) heart failure remains relatively limited.

Linear Trap Quadropole (LTQ) OrbiTrap mass spectrometry is a protein quantification strategy that provides relative and absolute measurements of proteins in complex mixtures (7). The present study was undertaken to investigate the differential protein expressions that are associated with advanced heart failure irrespective of treatment. LTQ OrbiTrap mass spectrometry was used to analyze the expression profiles of energy metabolism-associated, calcium-binding and cytoskeletal proteins in post-MI heart failure and control groups. The aim of the present study was to identify the target proteins that are associated with the disease in order to provide novel diagnostic markers and alternative therapies to reconstitute the energetic state and disrupt the damaging cycle of the failing heart.

\section{Materials and methods}

Acute heart failure model. All animal procedures and experiments were performed in accordance with the Guide for the Care and Use of Laboratory Animals published by the US National Institutes of Health [NIH publication 85(23), revised in 1996] (8). A total of 18 male Wistar rats (age, 12-14 weeks; weight, $250-300 \mathrm{~g}$ ) were provided by the experimental animal center of Shandong University (Shandong, China). The rats were housed in a climate-controlled environment at 
a constant temperature of $22^{\circ} \mathrm{C}$, relative humidity $50 \%$ and a 12-h dark/light cycle. Rats were fed standard laboratory chow, and allowed access to food and water ad libitum. The present study was conducted with approval from the Ethics Committee of Shandong University (Shandong, China).

The left anterior descending coronary artery of 12 rats was occluded as described previously (9). Rats were anaesthetized on postoperative days 1 and 14 with an intraperitoneal injection of $40 \mathrm{mg} / 100 \mathrm{~g}$ chloral hydrate and the hearts were exposed. The left anterior descending coronary artery was ligated at 2-3 mm below the left auricle. The heart was repositioned in the chest and the chest was closed with a purse string suture. The animals were randomly divided into the following 3 groups (6 rats/group): Control group (untreated rats), the 1st day group (rats were euthanized on the 1st postoperative day) and the 14th day group (rats were euthanized on the 14th postoperative day). The left ventricles were obtained immediately following animal sacrifice and cut into two sections. The hearts were removed rapidly, the left and right atrium and right ventricle were removed and the left ventricle was divided into two parts along the long axis. One section was immersed in $4 \%$ paraformaldehyde at room temperature overnight, and the other section was immediately snap-frozen and stored in liquid nitrogen for further analysis.

On the 14th postoperative day (prior to euthanasia), acquired echocardiography was used to measure the left ventricular end-diastolic diameter (LVEDD), left ventricular end-systolic diameter (LVESD), left ventricular posterior wall end diastole and end systole (LVPWs and LVPWd, respectively), left ventricular ejection fraction (LVEF) and fractional shortening (FS).

Protein extraction. A $50 \mathrm{mg}$ sample was taken from the LV of each rat following animal sacrifice, which was immediately snap-frozen and stored in liquid nitrogen. The samples were placed in liquid nitrogen and ground into a fine powder, homogenized in a lysate buffer $(8 \mathrm{~mol} / 1$ urea, $1 \mathrm{~mol} / 1 \mathrm{DTT}$, cocktail of protease inhibitors, $1 \mathrm{mg} / \mathrm{ml}$ leupeptin, $1 \mathrm{mg} / \mathrm{ml}$ aprotinin, $1 \mathrm{mg} / \mathrm{ml}$ pepstatin, radioimmunoprecipitation buffer and $0.1 \%$ PSMF) as previously described (10) and then incubated on ice for $30 \mathrm{~min}$. The samples were further lysed by ultrasound for 3 cycles of $10 \mathrm{sec}$. The whole lysate was centrifuged for $15 \mathrm{~min}$ at $4^{\circ} \mathrm{C}$ and $14,000 \mathrm{x} \mathrm{g}$, and the supernatant was collected.

Sample processing. Protein concentrations of the lysates were determined using a Bicinchoninic Acid Protein Assay kit (Beyotime Institute of Biotechnology, Haimen, China). Protein extract (30 $\mu \mathrm{l}$ ) was mixed with $200 \mu \mathrm{l}$ urea-acetate (UA) buffer ( $8 \mathrm{M}$ urea in $0.1 \mathrm{~mol} / 1 \mathrm{Tris} / \mathrm{HCl}$; $\mathrm{pH} 8.5$ ) in a filter unit, centrifuged at $14,000 \mathrm{x} \mathrm{g}$ at $4^{\circ} \mathrm{C}$ for $15 \mathrm{~min}$ and then washed three times with $100 \mu \mathrm{l}$ UA buffer. The flow-through was discarded from the collection tube. The concentrate was mixed with $100 \mu 1$ indole acetic acid buffer $(0.05 \mathrm{~mol} / \mathrm{l}$ iodoacetamide in UA) and incubated in the dark at room temperature for $20 \mathrm{~min}$, which was followed by centrifugation for $10 \mathrm{~min}$ at $14,000 \mathrm{x} \mathrm{g}$. The concentrate was then washed twice with $100 \mu$ l UA buffer followed by two washes with $100 \mu \mathrm{l}$ ammonium bicarbonate (ABC) buffer $\left(0.05 \mathrm{M} \mathrm{NH}_{4} \mathrm{HCO}_{3}\right.$ in water). A total of $40 \mu \mathrm{l}$ ABC buffer with trypsin (1:100) was added to the filter and incubated overnight at $37^{\circ} \mathrm{C}$ to achieve complete digestion. A further $40 \mu \mathrm{l} \mathrm{ABC}$ buffer was added and centrifuged at $14,000 \times \mathrm{g}$ for $10 \mathrm{~min}$. The final solution was dried under a vacuum and stored in a freezer at $-80^{\circ} \mathrm{C}$.

Sample purification with C18 Ziptip column. Samples were diluted in $40 \mu \mathrm{l} 0.1 \%$ trifluoroacetic acid (TFA). A total of $200 \mu 1100 \%$ acetonitrile was added to a Ziptip (Merck KGaA, Darmstadt, Germany) and centrifuged at $800 \mathrm{x} g$ for $2 \mathrm{~min}$; this step was repeated twice. The concentrate was mixed with $200 \mu 10.1 \%$ TFA and centrifuged at $800 \mathrm{x}$ g for 2 min. TFA was added and centrifugation was performed eight times. The Ziptip was washed twice with $0.1 \%$ TFA and centrifuged at $800 \mathrm{x}$ g for $2 \mathrm{~min}$. The peptides were eluted with $40 \mu \mathrm{l}$ formic acid, dried under a vacuum and stored in a freezer at $-80^{\circ} \mathrm{C}$.

LTQ OrbiTrap mass spectrometry. A total of four injections were made into a Nano LC 1000 (Proxeon; Thermo Fisher Scientific, Inc.) interface of the LTQ OrbiTrap elite mass spectrometer (Thermo Fisher Scientific, Inc.) via a nano source. Samples of $2 \mu \mathrm{g}$ were diluted in Solvent A $(99.9 \%$ water $/ 0.1 \%$ formic acid) and loaded onto a $150 \mu \mathrm{m} \times 2 \mathrm{~cm}$ peptrap $300 \AA \mathrm{C} 18$ pre-column. A total of $2 \mu \mathrm{g}$ peptide was eluted into a $75 \mu \mathrm{m} \times 25 \mathrm{~cm} 100 \AA \mathrm{C} 18$ analytical column (self-packed) and separated with a linear gradient of 5-30\% Solvent B (99.9\% acetonitrile/0.1\% formic acid) for $5 \mathrm{~min}$ and then $69 \%$ Solvent B for $115 \mathrm{~min}$. The flow rate was $250 \mathrm{nl} / \mathrm{min}$. The survey scans were acquired in the OrbiTrap analyzer with 60,000 resolution at $400 \mathrm{~m} / \mathrm{z}$ and $275^{\circ} \mathrm{C}$. The automated gain control target was set at the level of $1 \times 10^{6}$. The 25 most intense ions were fragmented using collisionally induced dissociation in the linear ion trap. The precursor ions were fragmented with helium gas for $30 \mathrm{msec}$ with a normalized collision energy of 35. The dynamic exclusion parameters were set to exclude ions previously selected for fragmentation for $1 \mathrm{~min}$. All data were acquired in the reduced profile mode to accommodate further downstream processing.

Protein identification and quantification. Protein identification was accomplished using Proteome Discoverer v1.4 (Thermo Fisher Scientific, Inc.) and Mascot Server v2.4 software (www. matrixscience.com/server.html). The Mascot search engine was used to identify consolidated data in the Uniprot rat protein database (www.uniprot.org), with carbamidomethylation $+57,005$ selected as the fixed modification and oxidation of methionine $+15,995$ set as the variable modification. The mass tolerance was set at $10 \mathrm{ppm}$ and the MS/MS tolerance was set at $0.8 \mathrm{Da}(10)$. The trypsin enzymolysis maximum leakage cut-off value was set at 2 , and the important threshold value was set at 0.01 to ensure a false discovery rate of $<1 \%$. Protein quantification was obtained via unique peptides. $\mathrm{P}<0.05$ was considered significant for protein quantification. To designate significant alterations in protein expression, fold changes $<2.0$ were set as the cut-offs. This analysis was performed twice.

Bioinformatic analyses. Analyses of protein (and their genes) classification were performed with tools available on the Protein Analysis Through Evolutionary Relationships online classification system (PANTHER; pantherdb.org). 
Hematoxylin and eosin $(H \& E)$ staining. The myocardial tissue was embedded in conventional paraffin and sectioned into 5- $\mu \mathrm{m}$-thick slides. Sections were dewaxed in xylene at room temperature and rehydrated in graded ethanol (dehydrated ethanol for $5 \mathrm{~min}$, dehydrated ethanol for $5 \mathrm{~min}, 90 \%$ ethanol for $5 \mathrm{~min}, 90 \%$ ethanol for $5 \mathrm{~min}, 75 \%$ ethanol for $5 \mathrm{~min}$ and $75 \%$ ethanol for $5 \mathrm{~min}$ ). Following the standard process of H\&E staining (10\% hematoxylin for 3-5 min and $0.5 \%$ eosin for $1 \mathrm{~min}$ at room temperature) (11), the specimens were observed under a light microscope (Leica DM4000B; Leica Microsystems GmbH, Wetzlar, Germany; magnification, $\mathrm{x} 400$ ) and the ratio of myocardial cells to capillaries, the diameter of cardiomyocytes, cell density, capillary density, intracellular substance and intercellular space were examined in 5 randomly selected fields in order to evaluate the extent of myocardial hypertrophy.

Western blot analysis. The LTQ OrbiTrap protein expression results were validated via western blot analysis. Total protein extracts used for the western blot analysis were obtained using the aforementioned procedure. The samples containing $100 \mu \mathrm{g}$ of total proteins were separated using $6 \%$ SDS-PAGE and transferred onto polyvinylidene fluoride membranes (Merck KGaA) via electro-blotting. The membranes were incubated in TBST containing 5\% non-fat dried milk for $1 \mathrm{~h}$ at $25^{\circ} \mathrm{C}$. The membranes were probed overnight at $4{ }^{\circ} \mathrm{C}$ with rabbit anti-myosin 7 polyclonal antibody (cat. no. 22280-1-AP; ProteinTech Group, Inc., Chicago, IL, USA), rabbit anti-Vitamin D binding protein (VDBP) polyclonal antibody (cat. no. 16922-1-AP; ProteinTech), rabbit anti-gelsolin polyclonal antibody (cat. no. PB0198; Wuhan Boster Biological Technology, Ltd., Wuhan, China) and rabbit anti-Voltage-dependent L-type calcium channel subunit $\alpha 1 \mathrm{D}$ polyclonal antibody (cat. no. PB0286; Wuhan Boster Biological Technology, Ltd.). GAPDH (cat. no. 10494-1-AP; ProteinTech) was used as an internal control. All primary antibodies were used at a 1:1,000 dilution. Horseradish peroxidase goat anti-rabbit IgG antibodies (cat. no. SA00001-2; ProteinTech) were used as the secondary antibodies at a dilution of 1:2,000. The membranes were developed with enhanced chemiluminescence plus reagent (Beyotime Institute of Biotechnology) and bands were quantified by densitometry using ImageJ2x software (version 2.14.7; National Institutes of Health, Bethesda, MD, USA). Experiments were repeated independently 3 times.

Immunohistochemistry. The myocardial tissue was fixed in $4 \%$ paraformaldehyde at room temperature overnight, embedded in conventional paraffin and sectioned using an SP-9001 IHC staining kit (ZSGD-BIO, Beijing, China) into 5- $\mu$ m thickness in accordance with the manufacturer's protocol. Sections were dewaxed in xylene at room temperature, rehydrated in graded ethanol (dehydrated ethanol for $5 \mathrm{~min}$, dehydrated ethanol for $5 \mathrm{~min}, 90 \%$ ethanol for $5 \mathrm{~min}, 90 \%$ ethanol for $5 \mathrm{~min}$, $75 \%$ ethanol for $5 \mathrm{~min}$ and $75 \%$ ethanol for $5 \mathrm{~min}$ ) and incubated with $0.3 \%$ hydrogen peroxide to inactivate endogenous peroxidase activity. Antigen retrieval was achieved by incubating the slides at high pressure for $2 \mathrm{~min}\left(\sim 120^{\circ} \mathrm{C}\right)$ with sodium citrate (pH 6.0). Following blocking with goat serum (ZSGD-BIO) at $37^{\circ} \mathrm{C}$ for $30 \mathrm{~min}$, the sections were incubated with rabbit anti-myosin 7 polyclonal antibody (1:200; cat. no. 22280-1-AP;
ProteinTech), rabbit anti-VDBP polyclonal antibody (1:100; cat. no. 16922-1-AP; ProteinTech), rabbit anti-gelsolin polyclonal antibody (1:50; cat. no. PB0198; Wuhan Boster Biological Technology, Ltd.) or rabbit anti-Voltage-dependent L-type calcium channel subunit $\alpha 1 \mathrm{D}$ (Cav 1.3) polyclonal antibody (1:50; cat. no. PB0286; Wuhan Boster Biological Technology, Ltd.) overnight at $4^{\circ} \mathrm{C}$ and subsequently incubated with biotinylated secondary antibody working fluid at $37^{\circ} \mathrm{C}$ for $30 \mathrm{~min}$ (cat. no. SP 9001; IHC staining kit; ZSGB-BIO, Beijing, China). The specimens were stained with $0.05 \%$ 3,3'-diaminobenzidine for $1 \mathrm{~min}$ and re-dyed with 10\% hematoxylin for 3-5 min at room temperature. The specimens were observed under a light microscope (Leica DM4000B; Leica Microsystems $\mathrm{GmbH}$; magnification, x400) and photographed. Brown reaction granules observed in the cells indicated a positive result.

Statistical analysis. Data was analyzed using SPSS software (version 18.0; SPSS, Inc., Chicago, IL, USA). One-way analysis of variance followed by Tukey's multiple comparison test was used to determine the statistical differences among the post-MI and control groups. Data are presented as the mean \pm standard deviation. $\mathrm{P}<0.05$ was considered to indicate a statistically significant difference.

\section{Results}

Morphological alterations post-MI. To verify the establishment of the myocardial infarction model in rats, H\&E staining of the cardiomyocytes was performed. In the control group specimens, a neat arrangement and clearly visible stripes were observed in cardiomyocytes. Conversely, the cardiomyocytes from the 1st and 14th day groups exhibited varying sizes and uneven staining. In addition, an increase in cell diameter and intercellular space, and an irregular arrangement of cardiac muscle fibers was observed following MI (Fig. 1). This suggests that the arrangement of cardiomyocytes in post-MI groups is irregular when compared with the control group.

LTQ OrbiTrap analysis. The present study then identified the differentially expressed proteins in MI model rats. Data from the LTQ OrbiTrap experiments contained 1,709 unique proteins from the cardiac tissues of the 14th day group, which included well-known markers associated with the cytoskeleton, energy metabolism and actin. In addition, 1,722 unique proteins were identified in the cardiac tissues of the 1st day group, and 2,148 unique proteins were observed in the cardiac tissues of the control group (Table I). Furthermore, 1,080 and 437 proteins were differentially expressed in the cardiac tissues of the 14th day group when compared with the 1st day group and the control group, respectively. When compared with the control group, 1,574 proteins were differentially expressed in the cardiac tissues of the 1st day group.

To identify proteins involved in post-MI heart failure, $<2.0$-fold expression was used as the cut-off. The results revealed that 99 proteins that were differentially expressed in the 14th and 1st day groups may be associated with the progression of heart failure. A further 100 proteins were differentially expressed between the 1st day and control groups. Comparisons between the control and 14th day groups revealed 78 differentially expressed proteins, including 
Table I. Proteins with statistically significant differential expression in cardiac tissues among the control, 1st and 14th day groups.

\begin{tabular}{|c|c|c|c|c|c|c|c|c|}
\hline \multirow[b]{3}{*}{ Group } & \multirow{3}{*}{$\begin{array}{l}\text { Protein } \\
\text { count }\end{array}$} & \multirow{3}{*}{$\begin{array}{l}\text { Peptide } \\
\text { count }\end{array}$} & \multicolumn{6}{|c|}{ Differentially expressed proteins } \\
\hline & & & \multicolumn{2}{|c|}{ Control vs. 1st day (fold >2) } & \multicolumn{2}{|c|}{ Control vs. 14th day (fold >2) } & \multicolumn{2}{|c|}{ 1st day vs. 14th day (fold $>2$ ) } \\
\hline & & & Upregulated & Downregulated & Upregulated & Downregulated & Upregulated & Downregulated \\
\hline Control & 2148 & 9243 & 45 & 55 & 50 & 28 & 48 & 51 \\
\hline 1st day & 1722 & 7473 & & & & & & \\
\hline 14th day & 1709 & 7541 & & & & & & \\
\hline
\end{tabular}

Control group, operation with no occlusion (untreated); 1st day group, tissues were taken from rats 1 day following surgical procedures; 14 th day group, tissues were taken from rats 14 days following surgical procedures.

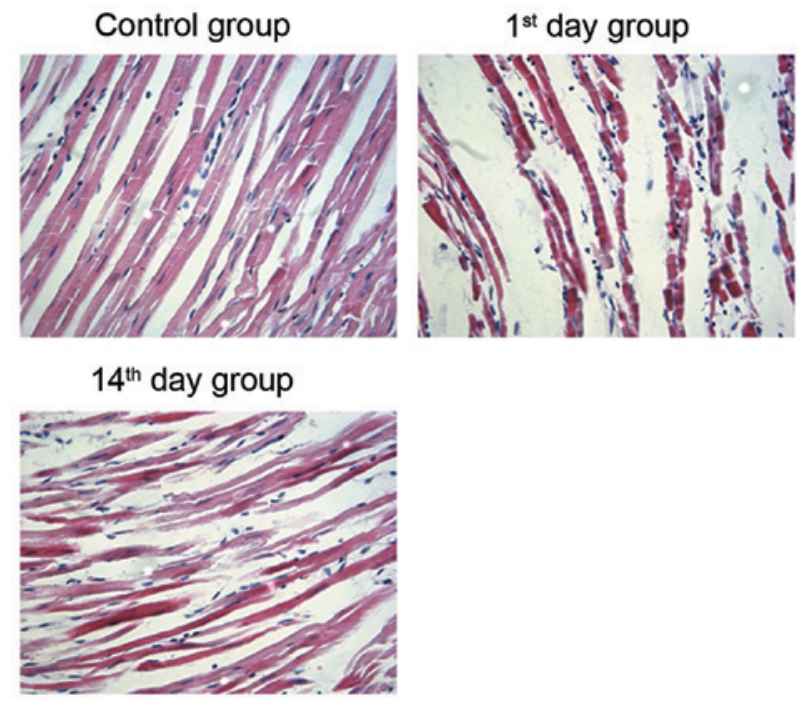

Figure 1. Morphological alterations in rat myocardial tissues visualized by H\&E staining. The left anterior descending coronary artery in rats was occluded, then on the 1st or 14th day following the operation, myocardial tissues were embedded in conventional paraffin, sectioned and stained with H\&E. Magnification, x400. H\&E, hematoxylin and eosin. Control group, operation with no occlusion (untreated); 1st day group, tissues were taken from rats 1 day following surgical procedures; 14th day group, tissues were taken from rats 14 days following surgical procedures.

50 upregulated proteins and 28 downregulated proteins in the control group (Table I).

The differentially expressed proteins in the control and 14th day groups are closely associated with energy metabolism (including glycolysis, mitochondrial tricarboxylic acid cycle and fatty acid $\beta$-oxidation), contractile function $[\beta$-myosin heavy chain isoforms (myosin-7)], calcium handling (Gelsolin, Cav 1.3, Galectin-3 and VDBP), pathologic hypertrophy (Gelsolin and Myosin-7) and cardiac remodeling (Fibrinogen $\beta$ chain; Table II). Furthermore, dynamic alterations in differential protein expression at different time points (the 1st and 14th postoperative days) post-MI were observed (Table III). For example, Myosin-7 expression was almost unaltered on the 1st day post-MI however, it was significantly upregulated on the 14th day post-MI with the progression of heart failure, which was in accordance with a previous study (12). In the acute phase of heart failure, namely in the 1st day post-MI group, expression of Gelsolin, Cav1.3 and VDBP increased significantly, with a fold increase of 3.92, 7.09 and 11.77, respectively, when compared with the control group.

Verification of protein expression by western blotting. The four dynamically altered proteins during the development of advanced heart failure were associated with a number of biological processes (Table III), thus their expression in myocardial tissues was verified by western blotting (Fig. 2). Consistent with the results of LTQ OrbiTrap, the expression of Myosin-7 was significantly upregulated on the 14th day post-MI with an unnoticeable alteration on the 1st day (Fig. 2A and B). The expression of VDBP was markedly upregulated on the 1st day post-MI (Fig. 2A and D) and the expression of Cav1.3 was significantly upregulated on the 14th day post-MI (Fig. 2A and E). The upregulation of Gelsolin on the 1st day post-MI was not observed by western blotting however, a marked upregulation was observed on the 14th day (Fig. 2A and $\mathrm{C}$ ). These results suggest that the present proteomics results are relatively reliable.

Verification of protein expression by immunohistochemistry. The present study further verified the aforementioned results via immunohistochemistry in the myocardial tissue at different time points post-MI. As presented in Fig. 3, Gelsolin, Myosin-7 and Cav1.3 were observed in the cytoplasm and nucleus of myocardial cells, and VDBP was highly expressed in the cell membrane. A similar expression profile for the four proteins during the progression of advanced heart failure was additionally observed.

\section{Discussion}

In the present study, quantitative proteomics based on LTQ OrbiTrap technology was used to evaluate differential protein expression during the development of heart failure post-MI in myocardial tissues. According to the PANTHER classification, a number of key enzymes in energy metabolism, including succinyl-CoA ligase (ADP/GDP-forming) subunit $\alpha$, isocitrate dehydrogenase (nicotinamide adenine dinucleotide) subunit $\alpha$, fumarate hydratase, aconitate hydratase, enoyl-CoA hydratase, enoyl-CoA $\Delta$ isomerase 1 , malate dehydrogenase, pyruvate dehydrogenase E1 component subunit $\alpha$, long-chain specific acyl-CoA dehydrogenase, very long-chain specific acyl-CoA dehydrogenase, carnitine O-acetyltransferase, 
Table II. Proteins with statistically significant differential expression between the control and 14th day groups.

\begin{tabular}{|c|c|c|c|c|c|}
\hline Accession & Peptides & P-value ${ }^{a}$ & Fold changes $^{\mathrm{a}}$ & Description & Function \\
\hline RS7_RAT & 1 & $7.86 \times 10^{-3}$ & 757.53 & 40S ribosomal protein $\mathrm{S} 7$ & \\
\hline SUCA_RAT & $3(2)$ & $3.10 \times 10^{-5}$ & 64.97 & $\begin{array}{l}\text { Succinyl-CoA ligase } \\
\text { [ADP/GDP-forming] subunit } \alpha\end{array}$ & Oxidoreductase \\
\hline STIM1_RAT & $6(1)$ & $8.62 \times 10^{-6}$ & 7.94 & Stromal interaction molecule 1 & \\
\hline PER1_RAT & $6(1)$ & $3.17 \times 10^{-3}$ & 7.51 & $\begin{array}{l}\text { Period circadian protein } \\
\text { homolog } 1\end{array}$ & $\begin{array}{l}\text { Transcription } \\
\text { cofactor }\end{array}$ \\
\hline ERAP1_RAT & $6(1)$ & $1.25 \times 10^{-3}$ & 6.7 & $\begin{array}{l}\text { Endoplasmic reticulum } \\
\text { aminopeptidase } 1\end{array}$ & Metalloprotease \\
\hline P97573 & $9(3)$ & 0.01 & 6.47 & $\begin{array}{l}\text { Phosphatidylinositol-3,4,5- } \\
\text { trisphosphate 5-phosphatase } 1\end{array}$ & Phosphatase \\
\hline PALM_RAT & $4(1)$ & 0.03 & 5.93 & Paralemmin-1 & \\
\hline MDHM_RAT & $7(2)$ & 0.03 & 5.43 & Malate dehydrogenase & Dehydrogenase \\
\hline ES1_RAT & $3(2)$ & $4.24 \times 10^{-3}$ & 3.71 & ES1 protein homolog & \\
\hline ACON_RAT & $8(3)$ & $2.04 \times 10^{-3}$ & 3.48 & Aconitate hydratase & Dehydrogenase \\
\hline ODPA_RAT & $5(3)$ & $9.40 \times 10^{-4}$ & 3.02 & $\begin{array}{l}\text { Pyruvate dehydrogenase } \\
\text { E1 component subunit } \alpha \text {, } \\
\text { somatic form }\end{array}$ & Dehydrogenase \\
\hline 3HIDH_RAT & $3(2)$ & 0.05 & 2.91 & $\begin{array}{l}\text { 3-hydroxyisobutyrate } \\
\text { dehydrogenase }\end{array}$ & Dehydrogenase \\
\hline H31_RAT & $5(2)$ & $1.29 \times 10^{-3}$ & 2.85 & Histone H3.1 & \\
\hline DESM_RAT & $7(3)$ & 0.01 & 2.83 & Desmin & Structural protein \\
\hline KCRS_RAT & $9(3)$ & $5.03 \times 10^{-4}$ & 2.81 & Creatine kinase S-type & Amino acid kinase \\
\hline DHSD_RAT & 1 & $1.09 \times 10^{-3}$ & 2.74 & $\begin{array}{l}\text { Succinate dehydrogenase } \\
\text { [ubiquinone] cytochrome b } \\
\text { small subunit }\end{array}$ & \\
\hline FUMH_RAT & $11(4)$ & 0.01 & 2.71 & Fumarate hydratase & Lyase \\
\hline CH60_RAT & $3(1)$ & 0.01 & 2.64 & $60 \mathrm{kDa}$ heat shock protein & Chaperonin \\
\hline ITB1_RAT & $7(4)$ & 0.01 & 2.52 & Integrin $\beta-1$ & \\
\hline SMC3_RAT & $25(4)$ & $2.99 \times 10^{-4}$ & 2.43 & $\begin{array}{l}\text { Structural maintenance of } \\
\text { chromosomes protein } 3\end{array}$ & \\
\hline THIOM_RAT & $2(1)$ & 0.04 & 2.4 & Thioredoxin & \\
\hline ATPO_RAT & $9(5)$ & $3.86 \times 10^{-3}$ & 2.39 & ATP synthase subunit Ol & ATP synthase \\
\hline GRP75_RAT & $16(3)$ & 0.03 & 2.34 & Stress-70 protein & \\
\hline ACADL_RAT & $8(4)$ & $7.38 \times 10^{-3}$ & 2.3 & $\begin{array}{l}\text { Long-chain specific acyl-CoA } \\
\text { dehydrogenase }\end{array}$ & Transferase \\
\hline ALDH2_RAT & $7(3)$ & 0.03 & 2.28 & Aldehyde dehydrogenase & \\
\hline ATP5E_RAT & $2(1)$ & $5.64 \times 10^{-3}$ & 2.19 & ATP synthase subunit epsilon & ATP synthase \\
\hline ATPB_RAT & $4(3)$ & $7.99 \times 10^{-4}$ & 2.14 & ATP synthase subunit $\beta$ & ATP synthase \\
\hline ECHM_RAT & $4(1)$ & $2.97 \times 10^{-3}$ & 2.1 & Enoyl-CoA hydratase & Acetyltransferase \\
\hline MAVS_RAT & 2 & 0.03 & 2.02 & $\begin{array}{l}\text { Mitochondrial } \\
\text { antiviral-signaling protein }\end{array}$ & \\
\hline ANXA6_RAT & $10(7)$ & $1.92 \times 10^{-5}$ & -2.07 & Annexin A6 & \\
\hline SPA3N_RAT & $2(1)$ & 0.02 & -2.08 & Serine protease inhibitor $\mathrm{A} 3 \mathrm{~N}$ & Serine protease inhibitor \\
\hline PSB1_RAT & $3(2)$ & $1.83 \times 10^{-3}$ & -2.1 & Proteasome subunit $\beta$ type-1 & Protease \\
\hline PGK1_RAT & $9(3)$ & $2.47 \times 10^{-4}$ & -2.16 & Phosphoglycerate kinase 1 & Carbohydrate kinase \\
\hline RL26_RAT & $4(1)$ & $9.18 \times 10^{-4}$ & -2.24 & $60 S$ ribosomal protein L26 & Ribosomal protein \\
\hline CDK7_RAT & $5(2)$ & 0.01 & -2.25 & $\begin{array}{l}\text { Cyclin-dependent kinase } 7 \\
\text { (Fragment) }\end{array}$ & $\begin{array}{l}\text { Non-receptor serine/ } \\
\text { threonine protein kinase }\end{array}$ \\
\hline FINC_RAT & $9(6)$ & $3.50 \times 10^{-3}$ & -2.28 & Fibronectin & Signaling molecule \\
\hline CHD8_RAT & $8(2)$ & $1.55 \times 10^{-3}$ & -2.31 & $\begin{array}{l}\text { Chromodomain-helicase-DNA- } \\
\text { binding protein } 8\end{array}$ & DNA helicase \\
\hline CDS2_RAT & 1 & 0.03 & -2.46 & $\begin{array}{l}\text { Phosphatidate } \\
\text { cytidylyltransferase } 2\end{array}$ & Nucleotidyltransferase \\
\hline
\end{tabular}


Table II. Continued.

\begin{tabular}{|c|c|c|c|c|c|}
\hline Accession & Peptides & P-value ${ }^{a}$ & Fold changes $^{\mathrm{a}}$ & Description & Function \\
\hline MYH7_RAT & $101(17)$ & $9.06 \times 10^{-6}$ & -2.48 & Myosin-7 & G-protein modulator \\
\hline APOH_RAT & 1 & $1.44 \times 10^{-3}$ & -2.53 & $\beta$-2-glycoprotein 1 & Apolipoprotein \\
\hline IGG2B_RAT & 2 & $6.88 \times 10^{-3}$ & -2.56 & Ig $\gamma-2 \mathrm{~B}$ chain $\mathrm{C}$ region & \\
\hline PABP1_RAT & $7(1)$ & $9.54 \times 10^{-5}$ & -2.77 & Polyadenylate-binding protein 1 & Transcription factor \\
\hline SELS_RAT & $3(1)$ & $5.32 \times 10^{-3}$ & -2.78 & Selenoprotein S & \\
\hline KACA_RAT & 1 & $3.62 \times 10^{-5}$ & -2.87 & Ig $\kappa$ chain $\mathrm{C}$ region, $\mathrm{A}$ allele & \\
\hline PPIB_RAT & $3(1)$ & 0.02 & -2.88 & $\begin{array}{l}\text { Peptidyl-prolyl cis-trans } \\
\text { isomerase B }\end{array}$ & Isomerase \\
\hline P06399 & $36(10)$ & $3.00 \times 10^{-6}$ & -2.88 & Fibrinogen $\alpha$ chain & \\
\hline HSDL2_RAT & $6(1)$ & $7.17 \times 10^{-3}$ & -2.9 & $\begin{array}{l}\text { Hydroxysteroid } \\
\text { dehydrogenase-like protein } 2\end{array}$ & Dehydrogenase \\
\hline DJC14_RAT & $5(2)$ & $5.49 \times 10^{-4}$ & -2.98 & Dnaj homolog & Chaperone \\
\hline C4BPA_RAT & $6(3)$ & $8.39 \times 10^{-3}$ & -3.02 & C4b-binding protein $\alpha$ chain & Apolipoprotein \\
\hline EXOC8_RAT & $6(1)$ & $2.70 \times 10^{-3}$ & -3.09 & Exocyst complex component 8 & \\
\hline GDIB_RAT & $3(1)$ & $1.76 \times 10^{-4}$ & -3.12 & Rab GDP dissociation inhibitor $\beta$ & Acyltransferase \\
\hline NDUA9_RAT & $3(2)$ & $6.17 \times 10^{-4}$ & -3.2 & $\begin{array}{l}\text { NADH dehydrogenase } \\
\text { [ubiquinone] } 1 \alpha \text { subcomplex } \\
\text { subunit } 9\end{array}$ & Dehydrogenase \\
\hline MVP_RAT & $4(2)$ & $1.37 \times 10^{-3}$ & -3.26 & Major vault protein & Ribonucleoprotein \\
\hline S10A3_RAT & 1 & $1.41 \times 10^{-3}$ & -3.28 & Protein S100-A3 & Calmodulin \\
\hline HBB2_RAT & $5(1)$ & $7.25 \times 10^{-3}$ & -3.58 & Hemoglobin subunit $\beta-2$ & \\
\hline FIBB_RAT & $10(6)$ & $1.68 \times 10^{-4}$ & -3.75 & Fibrinogen $\beta$ chain & Signaling molecule \\
\hline CEP41_RAT & $4(1)$ & $4.12 \times 10^{-4}$ & -3.9 & Centrosomal protein of $41 \mathrm{kDa}$ & \\
\hline AT5F1_RAT & $3(1)$ & 0.01 & -3.93 & $\begin{array}{l}\text { ATP synthase subunit } b \text {, } \\
\text { mitochondrial }\end{array}$ & \\
\hline GRM4_RAT & $5(2)$ & $6.43 \times 10^{-5}$ & -4.01 & $\begin{array}{l}\text { Metabotropic glutamate } \\
\text { receptor } 4\end{array}$ & $\begin{array}{l}\text { G-protein coupled } \\
\text { receptor }\end{array}$ \\
\hline PRELP_RAT & $4(1)$ & $1.31 \times 10^{-3}$ & -4.03 & Prolargin & Extracellular matrix protein \\
\hline FIBG_RAT & $8(4)$ & $8.81 \times 10^{-5}$ & -4.18 & Fibrinogen $\gamma$ chain OS & Signaling molecule \\
\hline IGG2A_RAT & $4(1)$ & $2.06 \times 10^{-3}$ & -4.76 & $\operatorname{Ig} \gamma-2 \mathrm{~A}$ chain $\mathrm{C}$ region & \\
\hline HEMO_RAT & $6(2)$ & $1.10 \times 10^{-3}$ & -4.84 & Hemopexin & Transfer/carrier protein \\
\hline LSG1_RAT & $4(1)$ & $5.76 \times 10^{-6}$ & -4.84 & Large subunit GTPase 1 homolog & Signaling molecule \\
\hline ZBT38_RAT & $11(2)$ & $1.86 \times 10^{-3}$ & -5.56 & $\begin{array}{l}\text { Zinc finger and BTB } \\
\text { domain-containing protein } 38\end{array}$ & $\begin{array}{l}\text { KRAB box } \\
\text { transcription factor }\end{array}$ \\
\hline RL10A_RAT & $5(1)$ & $3.82 \times 10^{-4}$ & -5.64 & 60S ribosomal protein L10a & Ribosomal protein \\
\hline PGS2_RAT & $4(1)$ & $6.25 \times 10^{-6}$ & -5.7 & Decorin & Extracellular matrix protein \\
\hline KNT1_RAT & $3(1)$ & $1.71 \times 10^{-3}$ & -5.96 & T-kininogen 1 & \\
\hline IGHG1_RAT & $3(1)$ & $5.69 \times 10^{-5}$ & -6.37 & Ig $\gamma-1$ chain $C$ region & \\
\hline PTGIS_RAT & $9(3)$ & $2.05 \times 10^{-5}$ & -6.76 & Prostacyclin synthase & Oxidoreductase \\
\hline CAC1D_RAT & $7(1)$ & $3.56 \times 10^{-3}$ & -7.46 & $\begin{array}{l}\text { Voltage-dependent L-type } \\
\text { calcium channel subunit } \alpha \text {-1D }\end{array}$ & $\begin{array}{l}\text { Voltage-gated calcium } \\
\text { channel }\end{array}$ \\
\hline ECI1_RAT & $4(1)$ & 0.04 & 9.73 & Enoyl-CoA $\Delta$ isomerase 1 & Acetyltransferase \\
\hline KNT2_RAT & $3(1)$ & $1.41 \times 10^{-4}$ & -16.47 & T-kininogen 2 & \\
\hline RS13_RAT & $2(1)$ & $1.04 \times 10^{-3}$ & -23.58 & 40S ribosomal protein $\mathrm{S} 13$ & Ribosomal protein \\
\hline SPRY4_RAT & $3(1)$ & 0.04 & -28.28 & Sprydomain-containing protein 4 & \\
\hline LEG3_RAT & $2(1)$ & $6.19 \times 10^{-6}$ & -36.14 & Galectin-3 & Signaling molecule \\
\hline PRP19_RAT & $3(1)$ & 0.02 & -68.84 & Pre-mRNA-processing factor 19 & mRNA splicing factor \\
\hline HD_RAT & $17(1)$ & $5.69 \times 10^{-3}$ & -366.94 & $\begin{array}{l}\text { Huntingtin, subfamily } \mathrm{C} \\
\text { member } 14\end{array}$ & \\
\hline
\end{tabular}

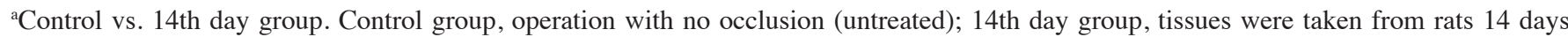
following surgical procedures. The numbers in brackets represent the number of peptides involved in the quantitative analysis. 
Table III. Dynamic changes in differential protein expression in cardiac tissues among the control, 1st and 14th day groups.

\begin{tabular}{|c|c|c|c|c|c|c|c|c|}
\hline Accession & Description & $\begin{array}{c}\text { Fold } \\
\text { change }^{\mathrm{a}}\end{array}$ & P-value ${ }^{a}$ & $\begin{array}{c}\text { Fold } \\
\text { change }^{b}\end{array}$ & P-value ${ }^{b}$ & $\begin{array}{c}\text { Fold } \\
\text { change }^{c}\end{array}$ & P-value ${ }^{c}$ & Function \\
\hline MYH7_RAT & Myosin-7 & -1.01 & $2.15 \times 10^{-5}$ & -2.48 & $9.06 \times 10^{-6}$ & 2.45 & $1.05 \times 10^{-5}$ & G-protein modulator \\
\hline GELS_RAT & Gelsolin & -3.92 & $1.70 \times 10^{-4}$ & -1.81 & $1.50 \times 10^{-5}$ & -2.16 & $4.40 \times 10^{-6}$ & $\begin{array}{l}\text { Non-motor actin } \\
\text { binding protein, } \\
\text { calcium-binding } \\
\text { protein }\end{array}$ \\
\hline CAC1D_RAT & Cav1.3 & -7.09 & $3.94 \times 10^{-3}$ & -7.46 & $3.56 \times 10^{-3}$ & 1.05 & $1.25 \times 10^{-3}$ & $\begin{array}{l}\text { Voltage-gated } \\
\text { calcium channel }\end{array}$ \\
\hline VTDB_RAT & VDBP & -11.77 & 0.01 & 1.23 & 0.01 & -13.65 & $8.10 \times 10^{-4}$ & \\
\hline
\end{tabular}

${ }^{\mathrm{a} C}$ Control vs. 1 st day group; ${ }^{\mathrm{b} C o n t r o l ~ v s . ~} 14$ th day group; ${ }^{\mathrm{c}} 14$ th day vs. 1 st day. Cav1.3, voltage-dependent L-type calcium channel subunit $\alpha$-1D; VDBP, vitamin D-binding protein; control group, operation with no occlusion (untreated); 1st day group, tissues were taken from rats 1 day following surgical procedures; 14th day group, tissues were taken from rats 14 days following surgical procedures.

A

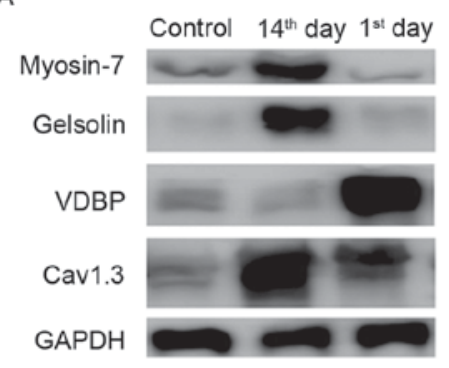

B

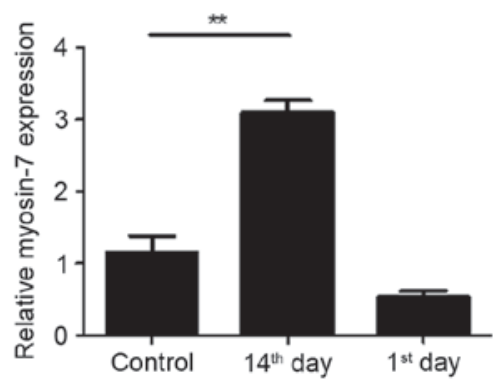

C

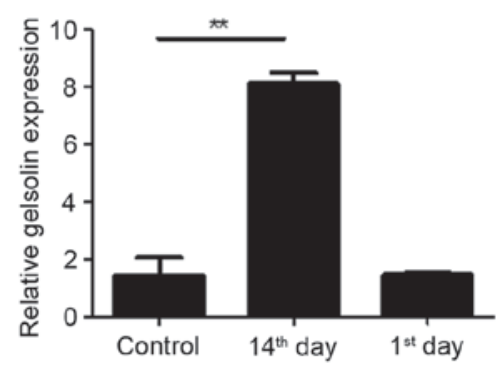

D

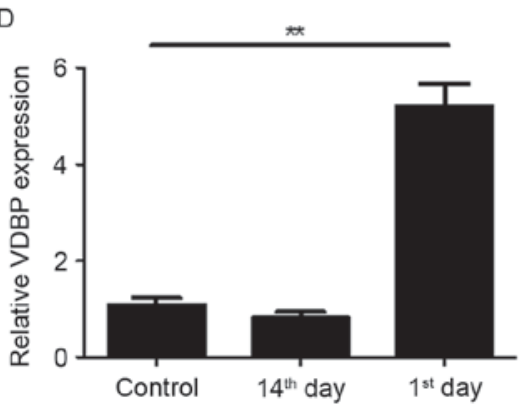

E

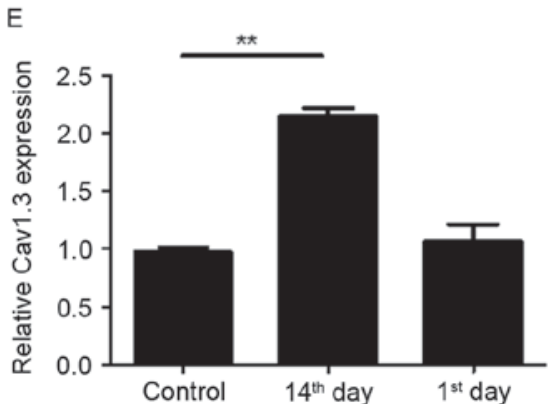

Figure 2. Western blot analysis to validate the alterations in the selected proteins identified by proteomic analysis. (A) Cell lysates were extracted from the left ventricle of untreated (control), 1st day post-MI and 14th day post-MI rats and analyzed by western blotting prior to quantification of (B) Myosin-7, (C) Gelsolin, (D) VDBP and (E) Cav1.3 protein expression. GAPDH was used to normalize expression levels. All experiments were performed at least twice. Data are presented as the mean \pm the standard deviation. ${ }^{* *} \mathrm{P}<0.01$. VDBP, vitamin D binding protein; Cav1.3, voltage-dependent L-type calcium channel subunit $\alpha 1 \mathrm{D}$; MI, myocardial infarction; control group, operation with no occlusion (untreated); 1st day group, tissues were taken from rats 1 day following surgical procedures; 14th day group, tissues were taken from rats 14 days following surgical procedures.

carnitine O-palmitoyl transferase 2, creatine kinase S-type and rhosphoglycerate kinase 1, were downregulated on the 1st and 14th day following MI when compared with the control group, which indicated that in the early and end stages of heart failure, the process of glycolysis and fatty acid $\beta$-oxidation are significantly decreased. Carnitine-palmitoyl transferase I (CPT1) is a rate-limiting enzyme mediating the mitochondrial uptake of fatty acid. It locates to the mitochondrial outer membrane to form fatty acylcarnitine, which catalyzes the conversion of long-chain acyl CoA to long-chain acylcarnitine. СРТ2, located on the mitochondrial inner membrane, converts acylcarnitine back to long-chain acyl CoA, releasing carnitine (13). Enoyl-CoA hydratase and acyl CoA dehydrogenase catalyze the rate-limiting step in mitochondrial fatty acid $\beta$-oxidation (14).

The majority of the previous, relevant studies demonstrated a pronounced decrease in the protein levels of various FFA $\beta$-oxidation enzymes in heart failure models, including human dilated cardiomyopathy (6), canine tachycardia induced heart failure $(15,16)$, rat aortic banding model (17) and rat chronic coronary ligation model (18). The decrease of FFA $\beta$-oxidation enzymes at the mRNA level was additionally reported in explanted hearts (19), dogs with end-stage tachycardia-induced heart failure (20) and dogs with microembolization-induced 
Control
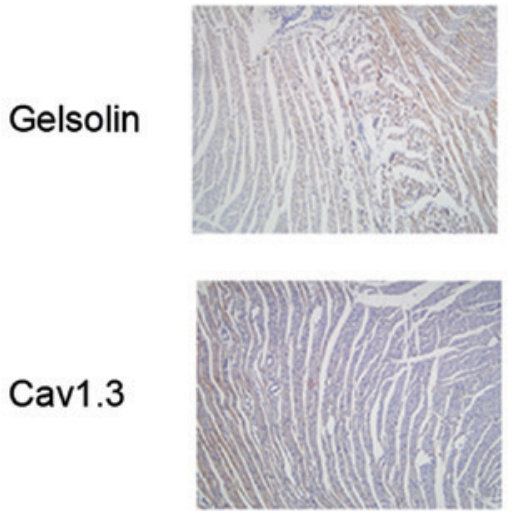

Cav1.3

Myosin-7
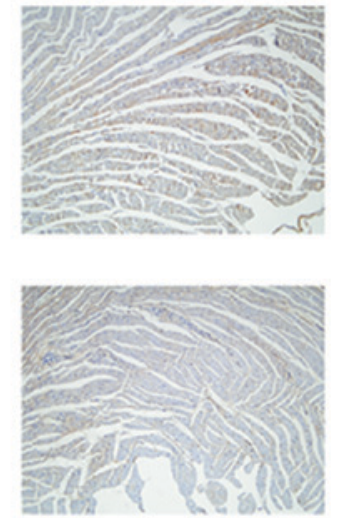

$14^{\text {th }}$ day
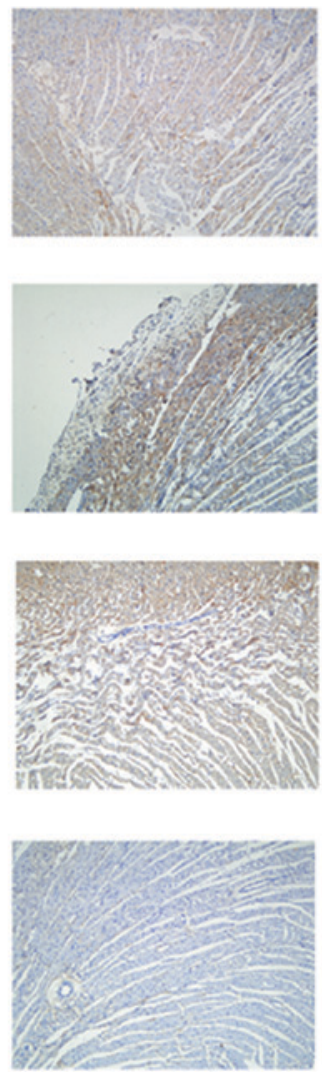

$1^{\text {st }}$ day
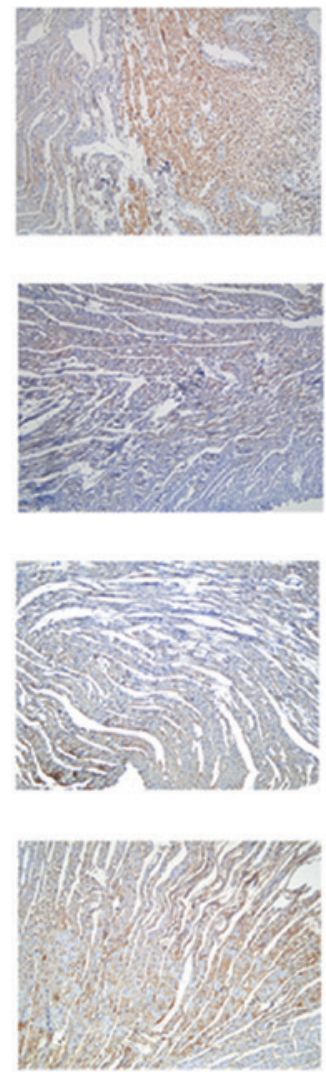

Figure 3. Immunohistochemistry validations of the alterations in the selected proteins identified by proteomic analysis. Myocardial tissues from untreated (control), 1st day post-MI and 14th day post-MI rats were embedded in conventional paraffin and the expression of Myosin-7, VDBP, Gelsolin and Cav1.3 were detected by immunohistochemistry staining using the appropriate antibodies (magnification, x400). VDBP, vitamin D binding protein; Cav1.3, voltage-dependent L-type calcium channel subunit $\alpha 1 \mathrm{D}$; MI, myocardial infarction; control group, operation with no occlusion (untreated); 1st day group, tissues were taken from rats 1 day following surgical procedures; 14th day group, tissues were taken from rats 14 days following surgical procedures.

heart failure (21). In addition, mRNA of the key enzymes involved in fatty acid uptake and FFA $\beta$-oxidation were decreased to a greater extent compared with their proteins and enzymatic activities, in the end stages of heart failure (22). It has been reported that peroxisome proliferator-activated receptor $\gamma$ coactivator-1 $\alpha$ (23), estrogen-related receptor $\alpha(20)$, peroxisome proliferator-activated receptor- $\alpha(21,24)$ and retinoid $\mathrm{X}$ receptor $\alpha$ (25) may regulate the mRNA expression of genes involved in the mitochondrial fatty acid metabolism pathway in human, mouse, rat and dog heart failure models $(20,23)$. Notably, in addition to carbohydrates and lipids, other metabolites, including certain amino acids and aldehydes, may influence energy status. Therefore, the defects in energy metabolism and decrease in cardiac muscle contractions are important factors in heart failure post-MI.

During systole, the opening of the L-type $\mathrm{Ca}^{2+}$ channel (LTCC) triggers sarcoplasmic reticulum (SR) $\mathrm{Ca}^{2+}$ release via the ryanodine-2 (RyR2) channels, and the $\mathrm{SR} \mathrm{Ca}^{2+}$ reuptake is conducted by the SR $\mathrm{Ca}^{2+}$ ATPase (SERCA). Conversely, the sodium-calcium exchanger (NCX) extrudes $\mathrm{Ca}^{2+}$ from the cardiomyocyte to maintain a steady-state condition. The $\left[\mathrm{Ca}^{2+}\right]$ i transient is conducted by sarcolemmal $\mathrm{Ca}^{2+}$ channels, which results in $\mathrm{Ca}^{2+}$ flux released from the SR via RyR2 channels. This $\mathrm{Ca}^{2+}$-induced $\mathrm{Ca}^{2+}$ release (CICR) is regulated by LTCC, which is localized to T-tubuli organization. The amplitude of the $\left[\mathrm{Ca}^{2+}\right] \mathrm{i}$ transient is dependent on the SR
$\mathrm{Ca}^{2+}$ content. The diastolic $\mathrm{Ca}^{2+}$ concentration is regulated by the $\left[\mathrm{Ca}^{2+}\right] \mathrm{i}$ transient decline, which is primarily due to SR $\mathrm{Ca}^{2+}$ reuptake through SERCA and extrusion of $\mathrm{Ca}^{2+}$ via the NCX. Calcium ion transport is abnormal in heart failure due to the increased diastolic $\mathrm{Ca}^{2+}$ levels, reduced $\mathrm{Ca}^{2+}$ sensitivity of myofilaments and decreased $\mathrm{Ca}^{2+}$ reuptake, which results in a diastolic $\mathrm{Ca}^{2+}$ overload (26-28).

In the present study, two proteins involved in calcium ion transport, Gelsolin and Cav1.3, were upregulated in the rat model of heart failure. Gelsolin is a widely-distributed calcium-regulated actin-binding protein which mediates cell motility, ion channel regulation, signal transduction (29) and multiple cytoskeletal remodeling (30). In addition, gelsolin has anti-apoptotic and pro-apoptotic functions (29). A previous study demonstrated with a post-MI model, that it is highly expressed in animal and human hearts and that it is associated with the progression of heart failure following MI, suggesting that gelsolin may serve an important role in cardiac remodeling post-MI (30). Li et al (31) used gelsolin-null mice and wild-type littermates to clarify the role of gelsolin in heart failure and the mechanism for gelsolin-stimulated apoptosis. The group revealed that a deficiency in gelsolin protects the heart post-MI. This protection is due in part, to the absence of gelsolin-mediated apoptosis following MI. Gelsolin is cleaved by caspase-3 between residues Asp352 and Gly353, and the N-terminal gelsolin fragment may induce apoptosis. 
Therefore, gelsolin acts as actin in a $\mathrm{Ca}^{2+}$-independent manner and it may promote morphological alterations during apoptosis, indicating that gelsolin facilitates MI-induced cardiomyocyte apoptosis. The results of the present study are in agreement with the findings of Li et al (31) as the gelsolin protein was upregulated in the 1st and 14th day groups post-MI.

Cav1.3 ( $\alpha 1 \mathrm{D})$ subunit (D-LTCC) is a component of LTCCs, which are vital for $\mathrm{Ca}^{2+}$ influx and are responsible for $\mathrm{Ca}^{2+}$ entry into cardiomyocytes during action potentials (32). Cav1.3 $\mathrm{Ca}^{2+}$ channels are highly expressed in cardiac pacemaking tissues [sinoatrial (SA) and atrioventricular nodes], and serve an important role in the spontaneous diastolic depolarization and pace making activities within SA node cells (33). Zhang et al (33) used a Cav1.3-null mutant mouse to illustrate that Cav1.3 $\mathrm{Ca}^{2+}$ channels were expressed in mouse atrial, however not ventricular tissues. The present study demonstrated that during the process of heart failure post-MI, the expression of Cav1.3 was upregulated in the left ventricular muscle. Therefore, it is possible that in the acute phase of heart failure, the $\beta$-adrenaline receptor is activated to trigger the opening of the LTCC and thus induces the influx of $\mathrm{Ca}^{2+}$, which in turn activates $\mathrm{Ca}^{2+}$ released from the SR.

Petrone et al (34) randomly selected 464 cases of heart failure and 464 controls to examine the expression of VDBP and revealed that there was no significant association between plasma levels of VDBP and risk of heart failure. In the present study, VDBP was significantly upregulated on the 1st day post-MI, then expression gradually declined with the progression of the disease. VDBP is an acute phase reactant (35) and its expression levels are upregulated in the acute phase of inflammation (36). VDBP expression may be increased by the pro-inflammatory cytokine interleukin-6 (37). In addition, this protein may associate with inflammatory cell surfaces (37). VDBP is a multifunctional transport protein for vitamin D metabolites (38), as vitamin D metabolism serves an important role in the maintenance of calcium homeostasis (39). VDBP binds to fatty acids and actin, preventing their polymerization, which may be detrimental in the circulatory system. VDBP may exert immune functions by inhibiting the production of $1,2,5(\mathrm{OH})_{2} \mathrm{D}_{3}$ in T-cells (40). It has been reported that $\sim 85-90 \%$ of $2,5(\mathrm{OH}) \mathrm{D}_{3}$ and $1,2,5(\mathrm{OH})_{2} \mathrm{D}_{3}$ in the circulation is bound to $\operatorname{VDBP}(41,42)$. Haddad et al (43) reported that serum VDBP does not decrease during vitamin D deficiency. Therefore, VDBP may protect against vitamin D deficiency, and it is fundamental for vitamin D dynamic homeostasis, as demonstrated in VDBP-null mice (39).

Vitamin D serves a major role in cardiac function by suppressing the parathyroid hormone, inhibiting renin, upregulating vascular endothelial growth factor and modulating calcium influx. Previous studies in animals $(44,45)$ have revealed the association between vitamin $\mathrm{D}$ and the cardiovascular system. Rats with experimentally induced vitamin D deficiency have been observed to develop heart failure with hypertension and cardiomegaly (46). Pilz et al (47) demonstrated the association between vitamin D deficiency and left ventricular hypertrophy. The group identified a negative correlation between 25-hydroxy vitamin $\mathrm{D}$ levels and the impairment of left ventricular function in a cross-sectional study of patients with coronary angiography (47).

Myosin-7, also known as cardiac $\beta$-myosin heavy chain, is a myocardial growth fetal gene that is associated with ventricular systolic function and remodeling ventricular pathological hypertrophy (48). In ventricular pathological hypertrophy and heart failure, contractile proteins and sarcomeres increase via the activation of myocardial growth fetal genes, including Myosin-7 (49). Abraham et al (50) studied the genes associated with phenotypic modulation in idiopathic dilated cardiomyopathy, and observed an increase in the mRNA expression of Myosin-7. In other models of ventricular pathological hypertrophy and heart failure, a coordinated decrease in $\alpha-M y H C$ mRNA and increase in Myosin-7 mRNA were associated with a reduction in shortening velocity (12). In addition, Myosin-7 has a lower myofibrillar $\mathrm{Ca}^{2+}$-stimulated ATPase activity than the $\alpha$-isoform, resulting in a reduction in shortening velocity and myocardial systolic function (12). Therefore, it has become apparent that intracellular $\mathrm{Ca}^{2+}$ homeostasis is vital for myocardial contractility $(7,9,10)$, and the capacity of the cardiac muscle to produce contractile force is dependent upon myofibrillar $\mathrm{Ca}^{2+}$-stimulated ATPase activity (51). Therefore, the relative amount of $\alpha$ - and $\beta$-myosin heavy chain isoforms determines myosin ATPase activity (52). Machackova et al (53) investigated the association between the alterations in gene expression and the heart failure phenotype. It was demonstrated that the $\beta$-myosin heavy chain proportion increased from 6.3 to $77.7 \%$ of total myosin heavy chain, whereas the $\alpha$-myosin heavy chain proportion decreased from 93.7 to $22.3 \%$ in post-MI heart failure.

In conclusion, the present proteomics study demonstrated that the profile of proteins associated with metabolic remodeling, calcium regulation and contractile function was altered in the presence of post-MI heart failure. At different time points (the 1st and 14th day post-MI), there are dynamic alterations in differential protein expression. Myosin-7, Gelsolin, VDBP and Cav1.3 were upregulated with the development of heart failure and, to the best of our knowledge, this is the first proteomic analysis of Myosin-7, Gelsolin, Cav1.3 and VDBP in a post-MI rat model using LTQ OrbiTrap. Therefore, these results may provide a comprehensive insight into the underlying mechanisms of the development of heart failure.

\section{Acknowledgements}

The authors would like to express their appreciation for the support provided by the cardiovascular internal medical staff at Shandong Provincial Hospital Affiliated with Shandong University (Jinan, China) during the present study. They would also like to thank the staff at the Cancer Center of the Medical College of Shandong University. The present study was supported by the Medical Science and Technology Development Program of Shandong Province (grant no. 2014WSA01015).

\section{References}

1. Hunt SA, Baker DW, Chin MH, Cinquegrani MP, Feldman AM, Francis GS, Ganiats TG, Goldstein S, Gregoratos G, Jessup ML, et al: ACC/AHA Guidelines for the evaluation and management of chronic heart failure in the adult: Executive summary a report of the American college of cardiology/american heart association task force on practice guidelines (Committee to Revise the 1995 Guidelines for the Evaluation and Management of Heart Failure): Developed in collaboration with the international society for heart and lung transplantation; endorsed by the heart failure society of America. Circulation 104: 2996-3007, 2001. 
2. Owan TE, Hodge DO, Herges RM, Jacobsen SJ, Roger VL and Redfield MM: Trends in prevalence and outcome of heart failure with preserved ejection fraction. N Engl J Med 355: 251-259, 2006

3. Bhatia RS, Tu JV, Lee DS, Austin PC, Fang J, Haouzi A, Gong Y and Liu PP: Outcome of heart failure with preserved ejection fraction in a population-based study. N Engl J Med 355: 260-269, 2006

4. Gradman AH and Alfayoumi F: From left ventricular hypertrophy to congestive heart failure: Management of hypertensive heart disease. Prog Cardiovasc Dis 48: 326-341, 2006.

5. Lopaschuk GD, Ussher JR, Folmes CD, Jaswal JS and Stanley WC: Myocardial fatty acid metabolism in health and disease. Physiol Rev 90: 207-258, 2010.

6. Paolisso G, Gambardella A, Galzerano D, D'Amore A, Rubino P, Verza M, Teasuro P, Varricchio M and D'Onofrio F: Total-body and myocardial substrate oxidation in congestive heart failure. Metabolism 43: 174-179, 1994.

7. Ross PL, Huang YN, Marchese JN, Williamson B, Parker K, Hattan S, Khainovski N, Pillai S, Dey S, Daniels S, et al Multiplexed protein quantitation in Saccharomyces cerevisiae using amine-reactive isobaric tagging reagents. Mol Cell Proteomics 3: 1154-1169, 2004.

8. National Research Council (US) Committee for the Update of the Guide for the Care and Use of Laboratory Animals: Guide for the Care and Use of Laboratory Animals. 8th edition. National Academies Press, Washington, DC, 2011.

9. Dixon IM, Lee SL and Dhalla NS: Nitrendipine binding in congestive heart failure due to myocardial infarction. Circ Res 66: 782-788, 1990.

10. Tang B, Li Y, Zhao L, Yuan S, Wang Z, Li B and Chen Q: Stable isotope dimethyl labeling combined with LTQ mass spectrometric detection, a quantitative proteomics technology used in liver cancer research. Biomed Rep 1: 549-554, 2013.

11. de Carvalho HF and Taboga SR: Fluorescence and confocal laser scanning microscopy imaging of elastic fibers in hematoxylin-eosin stained sections. Histochem Cell Biol 106: 587-592, 1996.

12. VanBuren P, Harris DE, Alpert NR and Warshaw DM: Cardiac V1 and V3 myosins differ in their hydrolytic and mechanical activities in vitro. Circ Res 77: 439-444, 1995.

13. Shibayama J, Yuzyuk TN, Cox J, Makaju A, Miller M, Lichter J, Li H, Leavy JD, Franklin S and Zaitsev AV: Metabolic remodeling in moderate synchronous versus dyssynchronous pacing-induced heart failure: Integrated metabolomics and proteomics study. PLoS One 10: e0118974, 2015.

14. Andresen BS, Olpin S, Poorthuis BJ, Scholte HR, Vianey-Saban C Wanders R, Ijlst L, Morris A, Pourfarzam M, Bartlett K, et al: Clear correlation of genotype with disease phenotype in very-long-chain acyl-CoA dehydrogenase deficiency. Am J Hum Genet 64: 479-494, 1999.

15. Osorio JC, Stanley WC, Linke A, Castellari M, Diep QN, Panchal AR, Hintze TH, Lopaschuk GD and Recchia FA: Impaired myocardial fatty acid oxidation and reduced protein expression of retinoid $\mathrm{X}$ receptor-alpha in pacing-induced heart failure. Circulation 106: 606-612, 2002.

16. Nikolaidis LA, Sturzu A, Stolarski C, Elahi D, Shen YT and Shannon RP: The development of myocardial insulin resistance in conscious dogs with advanced dilated cardiomyopathy. Cardiovasc Res 61: 297-306, 2004.

17. Allard MF, Schonekess BO, Henning SL, English DR and Lopaschuk GD: Contribution of oxidative metabolism and glycolysis to ATP production in hypertrophied hearts. Am J Physiol 267: H742-H750, 1994.

18. Heather LC, Cole MA, Lygate CA, Evans RD, Stuckey DJ, Murray AJ, Neubauer S and Clarke K: Fatty acid transporter levels and palmitate oxidation rate correlate with ejection fraction in the infarcted rat heart. Cardiovasc Res 72: 430-437, 2006

19. Sack MN, Rader TA, Park S, Bastin J, McCune SA and Kelly DP: Fatty acid oxidation enzyme gene expression is downregulated in the failing heart. Circulation 94: 2837-2842, 1996.

20. Lei B, Lionetti V, Young ME, Chandler MP, d'Agostino C, Kang E, Altarejos M, Matsuo K, Hintze TH, Stanley WC and Recchia FA: Paradoxical downregulation of the glucose oxidation pathway despite enhanced flux in severe heart failure. J Mol Cell Cardiol 36: 567-576, 2004.

21. Rosca MG, Vazquez EJ, Kerner J, Parland W, Chandler MP, Stanley W, Sabbah HN and Hoppel CL: Cardiac mitochondria in heart failure: Decrease in respirasomes and oxidative phosphorylation. Cardiovasc Res 80: 30-39, 2008.

22. Sihag S, Cresci S, Li AY, Sucharov CC and Lehman JJ: PGC-1alpha and ERRalpha target gene downregulation is a signature of the failing human heart. J Mol Cell Cardiol 46 201-212, 2009.
23. Barger PM, Brandt JM, Leone TC, Weinheimer CJ and Kelly DP: Deactivation of peroxisome proliferator-activated receptor-alpha during cardiac hypertrophic growth. J Clin Invest 105: 1723-1730, 2000 .

24. Morgan EE, Chandler MP, Young ME, McElfresh TA, Kung TA, Rennison JH, Tserng KY, Hoit BD and Stanley WC: Dissociation between gene and protein expression of metabolic enzymes in a rodent model of heart failure. Eur J Heart Fail 8: 687-693, 2006.

25. Bers DM: Altered cardiac myocyte Ca regulation in heart failure. Physiology (Bethesda) 21: 380-387, 2006.

26. Hobai IA and O'Rourke B: Decreased sarcoplasmic reticulum calcium content is responsible for defective excitation-contraction coupling in canine heart failure. Circulation 103: 1577-1584, 2001.

27. Piacentino V III, Weber CR, Chen X, Weisser-Thomas J, Margulies KB, Bers DM and Houser SR: Cellular basis of abnormal calcium transients of failing human ventricular myocytes. Circ Res 92: 651-658, 2003.

28. Tanaka M, Müllauer L, Ogiso Y, Fujita H, Moriya S, Furuuchi K, Harabayashi T, Shinohara N, Koyanagi T and Kuzumaki N: Gelsolin: A candidate for suppressor of human bladder cancer. Cancer Res 55: 3228-3232, 1995.

29. McGough AM, Staiger CJ, Min JK and Simonetti KD: The gelsolin family of actin regulatory proteins: Modular structures, versatile functions. FEBS Lett 552: 75-81, 2003.

30. Nishio R and Matsumori A: Gelsolin and cardiac myocyte apoptosis: A new target in the treatment of postinfarction remodeling. Circ Res 104: 829-831, 2009

31. Li GH, Shi Y, Chen Y, Sun M, Sader S, Maekawa Y, Arab S, Dawood F, Chen M, De Couto G, et al: Gelsolin regulates cardiac remodeling after myocardial infarction through DNase I-mediated apoptosis. Circ Res 104: 896-904, 2009.

32. Zhang Z, Xu Y, Song H, Rodriguez J, Tuteja D, Namkung Y, Shin HS and Chiamvimonvat N: Functional roles of $\mathrm{Ca}(\mathrm{v}) 1.3$ (alpha(1D)) calcium channel in sinoatrial nodes: Insight gained using gene-targeted null mutant mice. Circ Res 90: 981-987, 2002 .

33. Zhang Z, He Y, Tuteja D, Xu D, Timofeyev V, Zhang Q, Glatter KA, Xu Y, Shin HS, Low R and Chiamvimonvat N: Functional roles of Cav1.3(alpha1D) calcium channels in atria: Insights gained from gene-targeted null mutant mice. Circulation 112: 1936-1944, 2005.

34. Petrone AB, Weir NL, Steffen BT, Tsai MY, Gaziano JM and Djousse L: Plasma vitamin D-binding protein and risk of heart failure in male physicians. Am J Cardiol 112: 827-830, 2013.

35. Guha C, Osawa M, Werner PA, Galbraith RM and Paddock GV: Regulation of human Gc (vitamin D-binding) protein levels: Hormonal and cytokine control of gene expression in vitro. Hepatology 21: 1675-1681, 1995.

36. Petrini M, Galbraith RM, Werner PA, Emerson DL and Arnaud P: Gc (vitamin D binding protein) binds to cytoplasm of all human lymphocytes and is expressed on B-cell membranes. Clin Immunol Immunopathol 31: 282-295, 1984.

37. Gomme PT and Bertolini J: Therapeutic potential of vitamin Dbinding protein. Trends Biotechnol 22: 340-345, 2004.

38. Chun RF: New perspectives on the vitamin D binding protein. Cell Biochem Funct 30: 445-456, 2012.

39. Christakos S, Ajibade DV, Dhawan P, Fechner AJ and Mady LJ: Vitamin D: Metabolism. Endocrinol Metab Clin North Am 39: 243-253, 2010.

40. Kongsbak M, von Essen MR, Levring TB, Schjerling P, Woetmann A, Odum N, Bonefeld CM and Geisler C: Vitamin Dbinding protein controls $\mathrm{T}$ cell responses to vitamin D. BMC Immunol 15: 35, 2014.

41. Safadi FF, Thornton P, Magiera H, Hollis BW, Gentile M, Haddad JG, Liebhaber SA and Cooke NE: Osteopathy and resistance to vitamin $\mathrm{D}$ toxicity in mice null for vitamin $\mathrm{D}$ binding protein. J Clin Invest 103: 239-251, 1999.

42. Bikle DD, Gee E, Halloran B, Kowalski MA, Ryzen E and Haddad JG: Assessment of the free fraction of 25-hydroxyvitamin $D$ in serum and its regulation by albumin and the vitamin D-binding protein. J Clin Endocrinol Metab 63: 954-959, 1986.

43. Haddad JG, Fraser DR and Lawson DE: Vitamin D plasma binding protein. Turnover and fate in the rabbit. J Clin Invest 67: $1550-1560,1981$.

44. Weishaar RE and Simpson RU: Vitamin D3 and cardiovascular function in rats. J Clin Invest 79: 1706-1712, 1987.

45. Weishaar RE, Kim SN, Saunders DE and Simpson RU: Involvement of vitamin D3 with cardiovascular function. III. Effects on physical and morphological properties. Am J Physiol 258: E134-E142, 1990. 
46. Dorsch MP, Nemerovski CW, Ellingrod VL, Cowger JA Dyke DB, Koelling TM, Wu AH, Aaronson KD, Simpson RU and Bleske BE: Vitamin D receptor genetics on extracellular matrix biomarkers and hemodynamics in systolic heart failure. J Cardiovasc Pharmacol Ther 19: 439-445, 2014.

47. Pilz S, Mürz W, Wellnitz B, Seelhorst U, Fahrleitner-Pammer A Dimai HP, Boehm BO and Dobnig H: Association of vitamin D deficiency with heart failure and sudden cardiac death in a large cross-sectional study of patients referred for coronary angiography. J Clin Endocrinol Metab 93: 3927-3935, 2008.

48. Nadal-Ginard B and Mahdavi V: Molecular basis of cardiac performance. Plasticity of the myocardium generated through protein isoform switches. J Clin Invest 84: 1693-1700, 1989.

49. Nakao K, Minobe W, Roden R, Bristow MR and Leinwand LA Myosin heavy chain gene expression in human heart failure. J Clin Invest 100: 2362-2370, 1997.
50. Abraham WT, Gilbert EM, Lowes BD, Minobe WA, Larrabee P, Roden RL, Dutcher D, Sederberg J, Lindenfeld JA, Wolfel EE, et al: Coordinate changes in Myosin heavy chain isoform gene expression are selectively associated with alterations in dilated cardiomyopathy phenotype. Mol Med 8: 750-760, 2002.

51. Machackova J, Barta J and Dhalla NS: Myofibrillar remodeling in cardiac hypertrophy, heart failure and cardiomyopathies. Can J Cardiol 22: 953-968, 2006.

52. Dhalla NS, Saini-Chohan HK, Rodriguez-Leyva D, Elimban V, Dent MR and Tappia PS: Subcellular remodelling may induce cardiac dysfunction in congestive heart failure. Cardiovasc Res 81: 429-438, 2009.

53. Machackova J, Sanganalmath SK, Elimban V and Dhalla NS: $\beta$-adrenergic blockade attenuates cardiac dysfunction and myofibrillar remodelling in congestive heart failure. J Cell Mol Med 15: 545-554, 2011. 